\title{
Analisis Kondisi Sosial Ekonomi Masyarakat Daerah Transmigran
}

\author{
Abdulrahim Maruwae 1), Ardiansyah 2) \\ 1),2)Dosen Jurusan Pendidikan Ekonomi, Universitas Negeri Gorontalo \\ rullyntmaruwae@gmail.com
}

\begin{abstract}
This study intends to describe how the socioeconomic conditions of the transmigrant area community. This research uses descriptive qualitative method by using Milles and Huberman analysis design. The research findings show there are social interactions that are established within the community within the framework of harmony and tolerance that is continuously maintained. The values of local wisdom continue to be preserved along with the close social relations of the community. The level of education is still relatively low, with $66 \%$ of the population only graduating from junior high school, elementary school or not even attending school, but the population structure shows that $73 \%$ of the population is at productive age. The majority of the people's livelihoods are farmers, who manage their land with a variety of commodities including coconut, sugar cane, crops, fruits, and vegetables. The income earned by the community is, on average, sufficient to meet their daily needs. It can be concluded that the socioeconomic conditions of the Banuroja transmigrant community, both transmigrant, local and mixed communities show variations in the prestige or level of achievement of several indicators of socioeconomic conditions.
\end{abstract}

Keyword: Socioeconomic; Society; Transmigrant Area

\section{Pendahuluan}

Kurang lebih tiga dasawarsa negara ini menerapkan model pembangunan yang menekankan pada laju pertumbuhan ekonomi dan pendapatan per kapita. Penerapan model pembangunan semacam ini pada awalnya diawali dengan modernisasi pada seluruh aspek kehidupan masyarakat yang menjadi kerangka pikir yang melandasi kebijakan dan praktik pembangunan di Indonesia. Peralihan rezim beberapa dekade yang lalu hingga kini menuju totalitas demokrasi dianggap oleh banyak kalangan sebagai implikasi dari kebijakan pembangunan di zaman orde baru. Problem masyarakat dimasa lalu maupun yang dirasakan sampai saat ini begitu meresahkan dan menuntut penanganan segera. Problem yang kian mengemuka belakangan ini masih berkutat dengan persoalan-persoalan sosial dan pemerataan kesejahteraan. Sumbangsi pembangunan tampaknya belum mampu meningkatkan kemakmuran kalangan akar rumput. Dari banyak data yang dipublis, penduduk yang masih perlu mendapatkan perhatian yakni 
golongan masyarakat miskin dan banyak tersebar di wilayah perdesaan. Banyak studi yang mengungkap keterkaitan yang sangat kuat antara kondisi sosial ekonomi dengan tingkat pendidikan. Semakin tinggi tingkat pendidikan masyarakat berbanding lurus dengan tingkat sosial ekonomi masyarakat di suatu daerah. Basrowi dan Juariyah (2010) dalam penelitiannya mengungkapkan bahwa semakin tinggi tingkat pendidikan yang dicapai masyarakat maka semakin tinggi pula kondisi sosial ekonomi masyarakat tersebut, demikian sebaliknya semakin rendah tingkat pendidikan masyarakat maka semakin rendah pula kondisi sosial ekonomi masyarakat tersebut.

Seiring berkembangnya zaman, seakan menggeser anggapan masyarakat perdesaan yang memandang status pendidikan tidak menjamin lepasnya belenggu kemisikinan maupun mapannya kesejahteraan seseorang. Namun, perhatian masyarakat tentang pentingnya pendidikan sudah terlihat dari semakin menurunnya tingkat melek huruf dan buta aksara serta tingginya partisipasi sekolah dari tahun ke tahun. Kondisi yang sering terungkap di daerah perdesaan tersebut bukan lagi menjadi hambatan dalam pembangunan desa dan pemberdayaan masyarakatnya.

Aspek lain yang perlu diperhatikan selain tingkat pendidikan yaitu latar belakang budaya baik suku maupun agama, interaksi dan nilai sosial yang terbangun dalam masyarakat, mata pencaharian serta kepemilikan lahan dan tempat tinggal. Hal ini sejalan dengan yang dikemukakan oleh Yuliati (2003) bahwa kondisi sosial ekonomi sebagai kaitan antara status social dan kebiasaan hidup sehari-hari yang telah membudaya bagi individu atau kelompok, dimana kebiasaan hidup yang membudaya ini disebut dengan culture activity. Lebih lanjut dijelaskan juga bahwa semua masyarakat di dunia baik yang sederhana maupun kompleks, pola interaksi atau pergaulan hidup antara individu menunjuk pada perbedaan kedudukan dan derajat atau status kriteria dalam membedakan status pada masyarakat yang kecil biasanya sangat sederhana, karena di samping jumlah warganya yang relatif sedikit, juga orang-orang semua yang dianggap tinggi statusnya tidak begitu banyak jumlah maupun ragamnya.

Interaksi dan nilai sosial yang terbangun dalam masyarakat dengan latar belakang budaya yang berbeda (baik suku maupun agama) menjadi lebih menarik untuk dibahas. Kondisi dimaksud menjadi lebih mudah diamati pada daerah perdesaan yang dihuni ragam etnis masyarakat. Daerah yang dapat memberi ruang untuk mengulas objek penelitian yang mengakomodasi keragaman etnis masyarakat yaitu wilayah perdesaan masyarakat transmigran. Tinjauan sosial ekonomi menjadi lebih berwarna karena menyuguhkan keragaman aspek sosial, budaya dan ekonomi.

Salah satu daerah transmigran yang dijadikan rujukan yaitu Desa Wisata Banuroja yang terletak di Kecamatan Randangan, Kabupaten Pohuwato Provinsi Gorontalo. Dibandingkan daerah transmigran lainnya, Desa Banuroja memiliki 
kekhasan tersendiri. Penduduk Banuroja merupakan masyarakat yang berasal dari sembilan daerah yaitu Bali, Jawa, Sasak, Gorontalo, Sunda, Minahasa, Bugis, Betawi, dan Batak. Keragaman etnis tersebut diikuti dengan kepercayaan penduduknya yang berbeda-beda pula, dimulai dari pemeluk agama Islam, Hindu, Kristen Protestan, dan Katholik. Berdasarkan beberapa penjelasan di atas, maka penulis tertarik melakukan kajian penelitian tentang "Analisis Kondisi Sosial Ekonomi Masyarakat Daerah Transmigran"

\section{Tinjauan Pustaka}

\section{Konsep Kondisi Sosial Ekonomi}

Kondisi sosial ekonomi merupakan suatu kedudukan yang secara rasional dan menetapkan seseorang pada posisi tertentu dalam masyarakat, yang memiliki ciri-ciri sebagai berikut:

1. Lebih berpendidikan

2. Mempunyai status sosial yang ditandai dengan tingkat kehidupan, kesehatan, pekerjaan dan pengenalan diri terhadap lingkungan

3. Mempunyai tingkat mobilitas ke atas lebih besar

4. Mempunyai ladang luas

5. Lebih berorientasi pada ekonomi komersil produk

6. Mempunyai sikap yang lebih berkenaan dengan kredit

7. Perkerjaan lebih spesifik. (Sumardi dan Evers dalam Basrowi, 2010:64)

Lebih lanjut Langumadi dan Harudu (2017) dalam penelitiannya mengungkapkan tinjauan sosial ekonomi masyarakat dapat dilihat dari tingkat pendidikan, kondisi perumahan, kesehatan, pendapatan dan pekerjaan. Penjelasan di atas memandang tingkat pendidikan, pemilikan modal, usaha, kesehatan, perumahan, pendapatan dan pekerjaan menggambarkan seseorang memiliki status sosial ekonomi dalam masyarakat. Sementara dalam penelitiannya Basrowi dan Juariyah (2010:62) mengungkapkan kondisi sosial ekonomi adalah posisi individu dan kelompok yang berkenaan dengan ukuran rata-rata yang berlaku umum tentang pendidikan, pemilikan barangbarang, dan partisipasi dalam aktivitas kelompok dari komunitasnya. Pendapat ini menambahkan unsur interaksi sosial yang dapat diwujudkan dalam partisipasi dalam aktivitas kelompok.

Menurut Sukirno (2004: 231) kondisi sosial ekonomi adalah sama pengertiannya dengan membahas suatu aspek kehidupan masyarakat yang bersangkutan, hal ini mengingat bahwa adanya kenyataan kehidupan tidak semata-mata ditentukan oleh faktor-faktor yang bersifat ekonomi akan tetapi ditentukan pula faktorfaktor non ekonomi atau faktor sosial, bahkan dapat dikatakan faktor sosial juga dapat menentukan tingkat ekonomi seseorang dan juga sebaliknya faktor ekonomi menentukan status sosial seseorang dalam lingkungan sosialnya. Pendapat tersebut menegaskan bahwa faktor sosial dan faktor ekonomi saling mempengaruhi dalam kehidupan masyarakat.

\section{Konsep Masyarakat Daerah Transmigran \\ Masyarakat adalah adanya} sejumlah orang atau individu yang tinggal dalam suatu wilayah tertentu 
yang mengadakan hubungan dan terikat oleh rasa solidaritas dan kepentingan bersama serta sadar akan norma-norma yang mengatur mereka dalam beradaptasi (Langumadi dan Harudu: 2014). Daerah transmigran merupakan daerah yang dihuni oleh masyarakat transmigran maupun non transmigran. Masyarakat transmigran adalah masyarakat yang mengikuti program transmigrasi yang dicanangkan oleh pemerintah yang berasal dari berbagai daerah di Indonesia, sementara masyarakat non transmigran adalah masyarakat lokal ataupun masyarakat asli yang sudah menetap di daerah tersebut sebelum adanya program transmigrasi.

Penjelasan di atas sejalan dengan penelitian yang dilakukan Nova (2016) membagi subjek penelitiannya ke dalam tiga golongan yaitu masyarakat transmigrasi umum, transmigrasi lokal dan masyarakat asli. Masyarakat transmigrasi umum merupakan masyarakat mengikuti program transmigrasi yang disponsori dan dibiayai secara keseluruhan oleh pemerintah melalui Depnakertrans. Jika dilihat masyarakat transmigrasi umum berasal dari luar Pulau Sulawesi. Masyarakat transmigrasi lokal merupakan masyarakat yang berpindah dalam satu daerah saja, seperti dari satu provinsi ke provinsi yang lain, dan bahkan mungkin terjadi dalam satu provinsi.

Program transmigrasi menurut Undang-Undang Nomor 15 Tahun 1997 tentang Ketransmigrasian dan Peraturan Pemerintah Nomor 2 Tahun 1999 tentang penyelenggaraan transmigrasi merupakan bagian integral dari pembangunan nasional yang bertujuan untuk meningkatkan kesejahteraan transmigrasi dan masyarakat sekitarnya, peningkatan dan pemerataan pembangunan daerah serta memperkukuh persatuan dan kesatuan bangsa.

Menurut Riady

transmigrasi merupakan alternatif penting dalam rangka memecahkan masalah kepadatan penduduk khususnya di Pulau Jawa. Masyarakat yang mengikuti program transmigrasi, pada umumnya merupakan kelompok masyarakat yang berpendapatan rendah, yang tidak mempunyai lahan yang cukup untuk mengembangkan usaha-usaha pertanian. ketersediaan lahan di tempat transmigrasi memberikan peluang bagi masyarakat untuk meningkatkan kesejahteraannya jika dibandingkan sebelum mengikuti program transmigrasi.

Dalam konteks program dan sasaran transmigrasi di atas, daerah transmigran bertransformasi menjadi tempat tinggal menetap bagi masyarakat dari berbagai etnis yang saling berinteraksi dalam membangun kerukunan dan kebersamaan serta berpotensi meningkatkan kesejahteraan hidupnya. Secara keseluruhan, masyarakat daerah transmigran dimaknai sebagai sekelompok orang yang saling berinteraksi dan tinggal di tempat tujuan transmigrasi dalam rangka meningkatkan taraf hidupnya dengan latar belakang etnis maupun agama yang berbeda-beda.

\section{Studi Pendahuluan}

Studi tentang kondisi sosial ekonomi masyarakat transmigran sudah banyak dilakukan sebelumnya. Namun tentunya perlu ada penelitian lanjutan untuk lebih memperkuat 
temuan penelitian sebelumnya serta dapat memperluas cakupan kondisi sosial ekonomi masyarakat transmigran yang tersebar di seluruh wilayah Indonesia. Adapun beberapa ulasan penulis mengenai penelitian yang berkaitan dengan masyarakat transmigran, diantaranya:

a. Penelitian yang dilakukan oleh Basrowi dan Juariyah (2010) membahas tentang kondisi kehidupan sosial ekonomi, tingkat pendidikan masyarakat Desa Srigading Kecamatan Labuhan Maringgai, Kabupaten Lampung Timur. Temuan penelitian menggambarkan bahwa kondisi sosial ekonomi masyarakat masih tergolong rendah, tingkat pendidikan masyarakat juga rendah, serta ada kecenderungan semakin tinggi tingkat ekonomi semakin tinggi tingkat pendidikan anak.

b. Penelitan yang dilakukan oleh Kohar (2010) beranjak dari asumsi bahwa dibalik pergumulan keragaman etnis dalam suatu wilayah, sangat dimungkinkan terjadi sentimen-sentimen kesukuan, kedaerahan, dan agama. Peneliti melakukan tinjauan lebih dalam mengenai konflik yang terjadi antara masyarakat asli Minangkabau dan masyarakat transmigran dari Jawa di daerah Lunang Silaut (Pesisir). Dalam penelitian ini ditemukan adanya ada dua faktor penyebab terjadinya konflik antara dua etnis ini yaitu faktor tanah dan faktor perbedaan pemahaman keagamaan.

c. Penelitian yang dilakukan oleh Nova (2016) membahas tentang dampak transmigrasi terhadap kehidupan sosial masyarakat.
Temuan penelitian menjelaskan kondisi masyarakat yang terbuka dan mudah dalam menjalin hubungan sosial yang baik hingga tercipta hubungan persaudaraan yang kokoh. Program transmigrasi yang dilaksanakan pemerintah dianggap berhasil karena telah membawa beberapa perubahan yang menunjukkan kemajuan untuk daerah Timpeh. Perubahan yang terjadi akibat asimilasi budaya tidak hanya pada aspek sosial dan budaya tapi juga pada aspek politik dan ekonomi. Perubahan dalam aspek politik ditandai dengan adanya pemekaran Kecamatan Timpeh pada tahun 2008 dari kecamatan Sitiung. Sementara dalam aspek ekonomi masyarakat transmigran yang dibekali dengan pengetahuan budidaya tanaman kelapa sawit mengakibatkan tumbuhnya perekonomian masyarakat transmigran sekaligus masyarakat setempat.

d. Penelitian yang dilakukan oleh Langumadi dan Harudu (2017) membahas tentang kondisi sosial ekonomi masyarakat transmigran di UPT Arongo. Temuan penelitian menggambarkan bahwa kondisi pendidikan masyarakat transmigran sebagian besar dikategorikan sedang, kondisi perumahan sebagian besar dikategorikan sedang, kondisi kesehatan sebagian besar dikatergorikan sedang, sementara kondisi pendapatan sebagian besar dikategorikan rendah.

e. Penelitian yang dilakukan oleh Hasanuddin (2018) membahas tentang kerukunan masyarakat 
multikultur di Desa Banuroja, Gorontalo. Temuan penelitian menunjukkan adanya tiga faktor pendukung terbangunnya kerukunan masyarakat multikultur dan agama yaitu solidaritas dari berbagai suku bangsa dan agama dalam bentuk toleransi; para tokoh masyarakat dalam menjaga keseimbangan dan kesetaraan masyarakat; dan peranan Pesantren Salafiyah Syafiiyah dalam menjaga kerukunan dan mempersatukan masyarakat.

Studi yang telah dijabarkan di atas, telah menghasilkan beberapa fokus kajian dalam memandang kehidupan masyarakat perdesaan khususnya masyarakat transmigran seperti aspek pendidikan, sosial, ekonomi, budaya, kesehatan, agama bahkan politik. Jika dalam penelitian terdahulu subjek penelitian merupakan masyarakat perdesaan ataupun masyarakat transmigran (baik transmigran umum maupun transmigran lokal) serta masyarakat asli, maka dalam penelitian ini ditambahkan subjek masyarakat campuran. Sehingga masyarakat perdesaan yang menjadi subjek dalam penelitian ini dibagi menjadi tiga golongan yang masing-masing disebut sebagai golongan masyarakat transmigran (baik transmigran umum maupun transmigran lokal), masyarakat lokal/asli (penduduk setempat) dan masyarakat campuran (yang dalam keluarganya telah melalui proses percampuran suku yang ditempuh dengan pernikahan antar suku yang berbeda).

Lokasi penelitian merupakan daerah yang sama dengan penelitan yang dilakukan Hasanuddin (2018). Namun, dalam tulisan ini fokus dan subjek penelitian agak berbeda karena lebih memperluas kajiannya pada kondisi sosial ekonomi dari tiga golongan masyarakat yang telah dijelaskan pada paragraf sebelumnya. Pembahasan melingkupi peran semua masyarakat Banuroja dalam menjaga kerukunan, kearifan lokal, interaksi sosial dan kecenderungan peranannya dalam meningkatkan taraf hidup dan etos kerja.

\section{Metode Penelitian}

Penelitian ini menetapkan setting penelitian di Desa Banuroja Kecamatan Randangan, Kabupaten Pohuwato. Penelitian ini dilaksanakan pada bulan Mei 2019. Berdasarkan tujuan penelitian yang ingin dicapai yaitu untuk mengetahui gambaran kondisi sosial ekonomi masyarakat daerah transmigran maka dalam penelitian ini menggunakan pendekatan deskriptif kualitatif dengan menggunakan desain analisis Milles dan Huberman.

Penelitian ini memfokuskan analisisnya pada kondisi sosial dan ekonomi masyarakat Desa Banuroja yang meliputi jumlah penduduk, jumlah $\mathrm{KK}$, latar belakang etnis, agama, interaksi sosial, kearifan lokal, usia, tingkat pendidikan, pekerjaan (mata pencaharian), komoditi yang dikelola masyarakat setempat, kepemilikan kekayaan (lahan, rumah tinggal, pendapatan, dll).

Subjek Penelitian yang berhasil diwawancarai sebanyak 45 responden untuk mewakili 349 KK yang ada di Desa Banuroja. Pengambilan sampel dalam penelitian ini menggunakan 
Proportional Stratified Random Sampling berdasarkan tiga golongan masyarakat yang sudah ditetapkan oleh peneliti. Di setiap golongan masyarakat tersebut juga memperhatikan keterwakilan mata pencaharian masyarakat yang terdiri dari Petani, Wiraswasta, PNS, Karyawan Swasta. Di samping itu, terdapat responden yang merupakan tokoh agama, tokoh masyarakat dan aparat desa.

Sumber data menggunakan data primer dan data sekunder. Teknik pengumpulan data diperoleh melalui studi pustaka, obrservasi partisipatif, wawancara dan dokumentasi. Data yang berhasil diperoleh, dilakukan analisis mendalam baik sewaktu di lapangan maupun setelah penelitian. Analisis data ditempuh melalui lima langkah yaitu menampilkan data, menyeleksi data, menyaring/reduksi data, menyajikan data dan penarikan kesimpulan.

\section{Pembahasan}

\section{Gambaran Umum Desa Banuroja}

Desa Banuroja merupakan salah satu desa yang berada dalam wilayah Kecamatan Randangan, Kabupaten Pohuwato Provinsi Gorontalo. Sebelum dimekarkan pada tahun 2003, Desa Banuroja sebelumnya termasuk wilayah Unit Pemukiman Transmigrasi (UPT) Marisa I Sub B. Pada tanggal 17 Januari 1981, UPT Marisa I Sub A dan UPT Marisa I Sub B melakukan penyatuan wilayah untuk membentuk sebuah desa bernama Manunggal Karya. Jadi, Desa Banuroja merupakan hasil pemekaran dari Desa Manunggal Karya.
Nama desa merupakan akronim dari etnis yang pertama kali bermukim di Desa Banuroja yaitu Bali, Nusa Tenggara, Gorontalo, dan Jawa. Namun, saat ini sudah berkembang menjadi sembilan etnis dengan menetapnya masyarakat yang berasal dari daerah Sunda, Minahasa, Bugis, Betawi, dan Batak. Kondisi ini menunjukkan kekhasan dari Desa Banuroja dibandingkan dengan daerah transmigran lainnya. Keragaman etnis tersebut diikuti dengan kepercayaan penduduknya yang berbeda-beda pula, dimulai dari pemeluk agama Islam, Hindu, Kristen Protestan, dan Katholik, Luas area wilayah Desa Banuroja sebesar 7,08 Km2, dengan jarak tempuh ke pusat kecamatan sejauh $5 \mathrm{~km}$. Desa Banuroja yang terbagi dalam 4 dusun, memiliki letak geografis sebelah utara berbatasan dengan Desa Sari Murni, sebelah timur berbatasan dengan Desa Manunggal Karya, sebelah selatan berbatasan dengan Desa Motolohu dan Desa Patuhu, sebelah barat berbatasan dengan Desa Sidorukun dan Desa Pelambane.

Jumlah penduduk Desa Banuroja sebanyak 1154 orang yang terbagi dalam 349 kepala keluarga dengan rincian 611 orang berjenis kelamin laki-laki dan 543 orang perempuan. Adapun rincian suku berdasarkan jumlah penduduk yaitu $37 \%$ berasal dari Bali, 26\% dari Jawa, $25 \%$ dari Sasak(Lombok) dan sisanya dari Gorontalo, Minahasa, Sunda, Bugis, Betawi dan Batak masingmasing di bawah $5 \%$. 
Untuk lebih jelasnya dapat dilihat pada gambar di bawah ini:

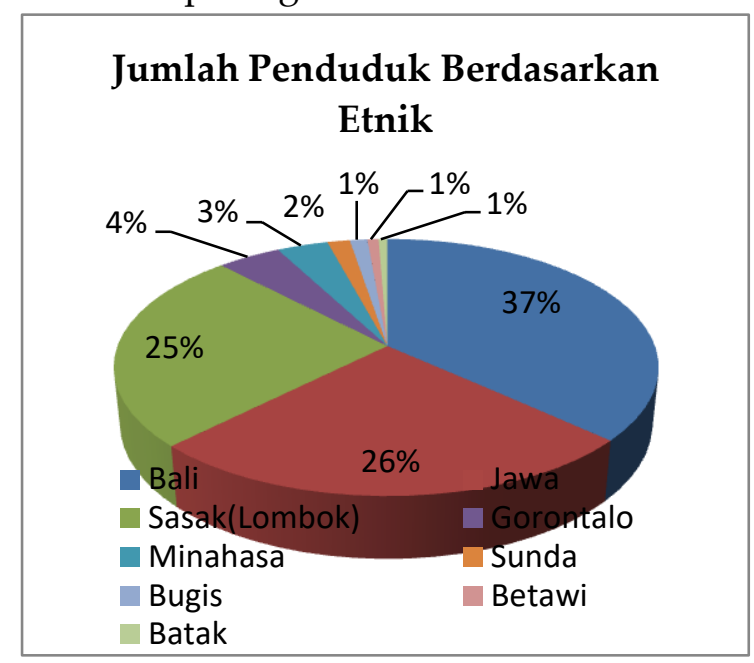

Sumber Data: Desa Banuroja 2019 (diolah)

Kepercayaan yang dianut penduduk Desa Banuroja tersebar dalam memeluk agama Islam sebanyak 638 orang, Hindu sebanyak 468 orang, Kristen Protestan sebanyak 41 orang dan Kristen Katholik sebanyak 7 orang. Presentase berdasarkan agama yang dianut masyarakat sebagai berikut:

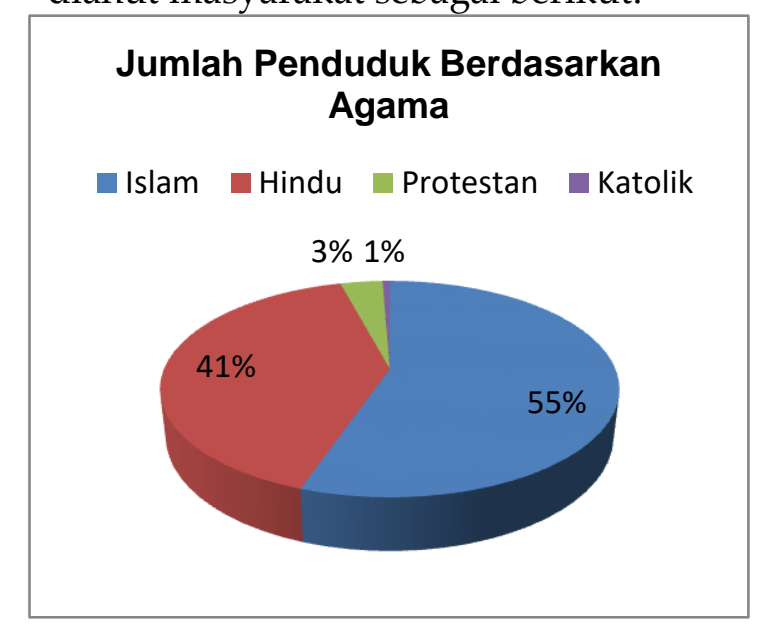

Sumber Data: BPS 2018 (diolah)

2.Kondisi Sosial Ekonomi Masyarakat

Studi Pustaka yang diperoleh menjadi tambahan informasi dalam penelitian ini yang dikombinasikan dengan hasil observasi di lokasi penelitian dan wawancara mendalam dengan masyarakat. Informan yang berhasil diwawancarai sebanyak 45 orang untuk mewakili 349 KK dengan latar belakang yang mencakup tiga golongan masyarakat (masyarakat transmigran, masyarakat lokal dan masyarakat campuran), agama (Islam, Hindu, Protestan, Katolik) dan mata pencaharian (petani, PNS, wiraswasta, buruh tani) yang ada di Desa Banuroja. Interaksi sosial yang terbangun dalam masyarakat Banuroja yang multikultur menunjukkan nuansa pola kehidupan keseharian yang rukun, damai, saling menghargai, toleran terhadap segala perbedaan. Hal ini terlihat dari respon dan penerimaan pemerintah desa dan semua informan pada saat studi penelitian yang begitu hangat dan sangat bersahabat. Tentu saja kondisi ini sejalan dengan banyak informasi yang mengulas tentang Banuroja, salah satunya dalam penelitan yang dilakukan Hasanuddin (2018: 22) diungkap bahwa masyarakat Banuroja merupakan potret dari keragaman masyarakat Indonesia, yang mampu mengkonstruksi sebuah keragaman identitas menjadi suatu kehidupan yang harmonis dan mampu menciptakan solusi bagi setiap gejolak yang terjadi dalam masyarakat tersebut.

Semua informan menyatakan bahwa masyarakat Banuroja memiliki sikap toleransi yang sangat tinggi. Dalam perayaan hari-hari besar keagamaan memberi ruang bagi suku dan agama yang berbeda saling berkunjung untuk bersilaturahmi. Dalam aktivitas mengelola lahan pertanian, masyarakat saling bertukar informasi dan saling membantu jika ada yang mengalami kesulitan.

Nilai-nilai kearifan lokal juga terus dilestarikan seiring dengan 
eratnya hubungan sosial masyarakat Banuroja, hal ini terungkap dari beberapa informan yang menyampaikan bahwa pada saat perayaan malam pasang lampu di bulan Ramadhan, masyarakat yang non muslim turut membantu dalam pemasangan lampu di ruas jalan maupun di rumah warga.

Tarian Bali sering dipentaskan jika ada kegiatan pemerintah desa maupun jika ada kunjungan Gubernur. Walaupun sudah membaur dengan berbagai suku dan agama, masyarakat Desa Banuroja tetap konsisten dalam menginternalisasikan nilai-nilai agama, adat istiadat, petuah nenek moyang sebagai pegangan hidup di lingkungan yang multikultur.

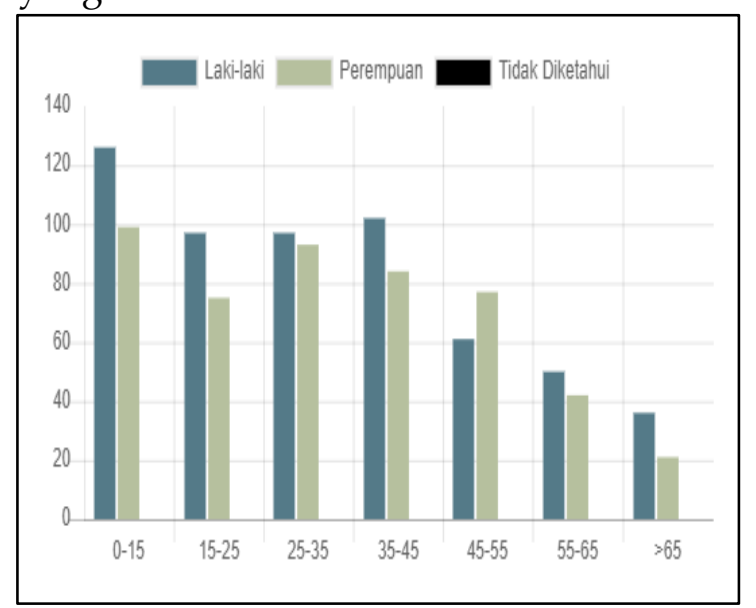

Sumber Data: Desa Banuroja 2019

Struktur penduduk Desa

Banuroja jika diperhatikan pada gambar di atas, dari usia maka dapat diklasifikasikan yang berusia di bawah 15 tahun sebesar $21 \%$, yang berusia 1565 tahun sebesar $73 \%$ dan yang berusia di atas 65 tahun sebesar $5 \%$.

Banyaknya penduduk Banuroja yang berusia 15-64 tahun merupakan fenomena yang potensial dalam mengawal pembangunan di masa mendatang. Tingginya angka usia produktif sebesar $73 \%$ menggambarkan adanya peluang yang dapat bermanfaat bagi Banuroja, ketika masyarakat di usia tersebut memilki kualitas dan mampu mengambil peran.

Tingkat pendidikan masyarakat Desa Banuroja sebagian besar hanya tamat SD sederajat baik yang berjenis kelamin laki-laki maupun perempuan, yakni sebesar $29 \%$. Diikuti yang tamat SLTA sederajat sebesar $15 \%$, yang tamat SLTP sederajat sebesar 13\%, tamat Perguruan Tinggi sebesar $10 \%$. Terdapat 9\% masyarakat yang sedang menempuh pendidikan pada jenjang TK dan SD. Di samping itu, masih terdapat sebesar $10 \%$ masyarakat yang belum/tidak sekolah, sisanya sebesar $14 \%$ tidak diketahui.

Data di atas menunjukkan tingkat pendidikan masyarakat Desa Banuroja masih tergolong rendah. Jika diakumulasi, masyarakat yang berpendidikan rendah yaitu antara SDSLTP, yang belum/tidak sekolah serta yang tidak diketahui secara keseluruhan mencapai $66 \%$. Sementara yang sedang menempuh pendidikan pada jenjang TK/SD yang sebesar 9\%, diharapkan terus melanjutkan pendidikannya di waktu mendatang. Hal tersebut dapat menambah sumbangsi tamatan SLTA dan Perguruan tinggi yang pada saat ini hanya mencapai angka $25 \%$.

Ketersediaan sarana dan prasarana pendidikan di Banuroja mudah dijangkau oleh masyarakat. Adapun daftar sekolah yang ada di Desa Banuroja yaitu SD, MI, SMP, MTS, SMK, dan MA masing-masing 1 unit. Untuk SMA hanya terdapat di pusat kecamatan, namun lokasinya masih dapat dijangkau karena hanya 
berjarak sekitar $5 \mathrm{~km}$ dari Desa Banuroja. Total jumlah siswa yang bersekolah pada Satuan Pendidikan yang ada di Banuroja yaitu sebanyak 911 orang dengan rincian SD sebanyak 144 siswa, Madrasah Ibtidaiyah (MI) sebanyak 230 siswa, SMP sebanyak 62 siswa, Madrasah Tsanawiyah (MTs) sebanyak 230 siswa dan Madrasah Aliyah (MA) 245 siswa.

Mata pencaharian masyarakat Desa Banuroja sebagian besar adalah petani, yakni sebesar $21 \%$. Sebagian yang lain adalah wiraswasta sebesar $4 \%$, PNS sebesar $4 \%$, buruh tani sebesar $3 \%$, yang tidak memiliki pekerjaan tetap dan lain-lain sebesar 9\%. Selain itu, terdapat $12 \%$ masyarakat yang belum bekerja serta $25 \%$ masyarakat yang sementara menempuh pendidikan.

Banyaknya masyarakat yang bekerja sebagai petani dapat disebabkan terbatasnya keahlian yang dimiliki serta ditunjang kondisi geografis yang sangat cocok untuk bertani kebun. Adapun komoditi yang dominan dihasilkan oleh masyarakat petani yaitu kelapa, tebu, palawija (jagung, kedelei, kacang tanah, kacang hijau), buah-buahan (jeruk, pisang, buah naga), dan sayuran (cabai, bawang merah, tomat, ketimun).

Sebagian besar responden yang diwawancarai memiliki lahan garapan sendiri. Masyarakat transmigran diberikan hak 2 hektar tanah, 1 hektar lahan olahan seluas $7500 \mathrm{~m}^{2}$ untuk lahan sawah. Namun karena wilayah Banuroja banyak perbukitan, menyebabkan Bendungan Randangan tidak menjangkau jalur irigasi untuk area persawahan. Kepemilikan rumah juga merupakan rumah milik sendiri.

\section{Pembahasan}

Kondisi sosial ekonomi masyarakat dapat ditinjau dalam berbagai aspek. Temuan penelitian menunjukkan adanya variasi prestise atau tingkat pencapaian dalam beberapa indikator kondisi sosial ekonomi masyarakat Banuroja. Masyarakat Banuroja yang multikultur, menunjukkan adanya pola kehidupan yang rukun, damai, toleran, saling menghargai dan menghormati terhadap segala bentuk perbedaan. Hubungan sosial yang terbangun dalam masyarakat, baik dari golongan transmigran, lokal, dan campuran berjalan dengan baik dan harmonis. Hubungan sosial yang harmonis ini dapat memberikan efek positif dalam setiap aktivitas masyarakat. Seperti meningkatnya semangat dalam mengelola lahan pertanian, karena terbukanya peluang kerjasama antar warga untuk saling bertukar informasi dan saling membantu jika ada yang mengalami kesulitan.

\section{Interaksi Sosial dan Kearifan Lokal}

Semua responden yang merepresentasi etnis, agama, pekerjaan yang berbeda menyatakan bahwa masyarakat Banuroja memiliki sikap toleransi yang sangat tinggi. Dalam perayaan hari-hari besar keagamaan, memberikan ruang bagi masyarakat multikultur saling berkunjung untuk bersilaturahmi. Hal ini juga pernah diungkap oleh Hasanudin (2018) bahwa terdapat tradisi yang unik dalam kehidupan masyarakat Banuroja yang sampai sekarang tetap terjaga. Tradisi tersebut adalah bersilaturahmi antar pemeluk agama pada hari besar agama masing-masing. Misalnya saat umat Islam merayakan Idul Fitri, 
warga pemeluk Hindu dan Kristen ikut serta meramaikan suasana. Warga pemeluk Hindu mengirimkan buahbuahan dan umat Kristiani menyerahkan aneka macam makanan kepada penduduk muslim yang merayakan.

Pembauran yang terjadi dalam masyarakat bukan hanya terjadi di saat perayaan hari besar keagamaan. Pada setiap kondisi seringkali petani dari masyarakat Bali maupun dari suku dan agama lainnya mendatangi tokoh masyarakat untuk berbagi informasi, berdiskusi, meminta solusi walaupun dengan latar belakang agama dan suku yang berbeda. Dengan adanya kerukunan dan persatuan yang terjalin dalam hubungan sosial masyarakat Banuroja, dapat menguatkan tekad dan semangat semua golongan masyarakat untuk meningkatkan taraf hidupnya.

Nilai-nilai kearifan lokal masih melekat pada masyarakat Banuroja. Walaupun sudah membaur dengan berbagai etnis dan agama, mereka tetap mempertahankan dan menjaga identintas asalnya sebagai wujud dalam melestarikan budaya daerah. Adapun kegiatan sosial yang terungkap, diantaranya jika ada warga yang menyelenggarakan hajatan atau pesta pernikahan, mereka saling membantu hingga lancarnya hajatan tersebut. Ada masyarakat yang memberikan beras, atau hasil panen yang bisa mereka berikan kepada orang yang berhajat. Sebagai kawasan transmigrasi, budaya yang melekat pada masyarakat Banuroja sudah banyak mengalami akulturasi seperti peringatan hari besar dan ritual keagaman yang dilaksanakan berdasarkan tradisi daerah masing- masing. Masyarakat yang beragama Islam misalnya modikili, tumbilotohe, me'raji yang merupakan tradisi Gorontalo; genduren/kenduri tradisi Jawa; rowah beretes tradisi Sasak(Lombok). Selain itu, jenis kesenian dan permainan rakyat yang masih dilaksanakan diantaranya, kesenian musik gamelan, qasidah, kuda lumping, wayang orang dan reog ponorogo.

\section{Usia Penduduk dan Tingkat Pendidikan}

Struktur penduduk Banuroja sebagian besar berada pada usia produktif yakni sebesar $73 \%$. Kondisi ini merupakan segmen potensial dalam mengembangkan kondisi daerah di masa mendatang. Bonus demografi ini harus dikelola dan disiapkan dengan matang oleh pemerintah. Fenomena yang mengemuka dewasa ini yaitu terbatasnya lapangan kerja yang tersedia. Jika dikaitkan dengan data dan informasi terkait pekerjaan penduduk, terdapat $25 \%$ yang sementara menempuh pendidikan. Kondisi tersebut mengambarkan adanya peluang mengembangkan kualitas masyarakat dari kalangan pelajar dan mahasiswa. Kompetensi yang terukur dari lulusan Perguruan Tinggi disertai dengan peran pemerintah dalam meningkatkan program wirausaha bagi pelajar dan mahasiswa diharapkan dapat menekan angka pengangguran sambil meraih peluang dari bonus demografi.

Partisipasi masyarakat Banuroja dalam meningkatkan pendidikan sebesar $25 \%$ dapat mengurangi kesenjangan tingkat pendidikan yang ditempuh masyarakatnya. Jika dibandingkan, masyarakat yang 
tergolong berpendidikan rendah sebesar 52\%, sedangkan masyarakat yang tergolong berpendidikan tinggi sebesar $25 \%$. Kondisi ini menunjukkan tingginya motivasi orang tua dalam menyekolahkan anaknya. Informasi yang diperoleh, rata-rata responden berusaha menyekolahkan anaknya bahkan sampai ke sekolah tinggi. Ketersediaan sarana dan prasarana pendidikan yang ada di Banuroja mulai dari jenjang pendidikan dasar sampai menengah atas turut memberikan jalan keluar bagi masyarakat dalam meningkatkan kualitas sumber daya manusianya.

Pandangan yang sering muncul dikalangan masyarakat perdesaan yang memandang status pendidikan tidak menjamin lepasnya belenggu kemisikinan maupun mapannya kesejahteraan seseorang perlahan-lahan mulai redup. Tidak bisa dipungkiri banyak studi yang menegaskan bahwa investasi pendidikan berperan untuk meningkatkan kompetensi dan keahlian seseorang serta dapat meningkatkan partisipasi masyarakat dalam pengembangan daerahnya. Jika semakin banyak masyarakat terdidik yang kreatif, Desa Banuroja akan semakin berkembang menjadi Desa wisata yang berpotensi ekonomi bagi masyarakatnya. Seperti dengan memanfaatkan hasil pertanian, melihat peluang sektor jasa pariwisata ataupun melalui ekonomi kreatif masyarakat.

Mata Pencaharian, Komoditi yang dikelola, Kepemilikan Kekayaan

Karakteristik wilayah Desa

Banuroja yang banyak terdapat area perbukitan dan jalur pengairan yang tidak tersedia dari Bendungan Randangan menyulitkan masyarakat membuka area persawahan. Pembukaan lahan perkebunan menjadi pilihan bagi masyarakat yang tidak memiliki pekerjaan tetap dan minim keahlian untuk dapat bertahan hidup. Sebagaimana data yang diperoleh serta ditunjang hasil wawancara, mata pencaharian sebagaian besar masyarakat Banuroja adalah sebagai petani. Adapun komoditi hasil pertanian yang dominan dihasilkan oleh masyarakat Banuroja yaitu kelapa, jagung, tebu, kedelei, kacang tanah, kacang hijau, jeruk, pisang, buah naga, cabai, bawang merah, dan tomat. Informasi yang diperoleh, sebagian besar masyarakat sangat bergantung dari hasil pertanian yang mereka garap menggunakan lahan milik sendiri.

Hasil panen masyarakat sangat bergantung pada kondisi cuaca, terkadang masyarakat pernah memperoleh hasil yang kurang maksimal atau gagal panen. Dengan kondisi seperti ini keutungan yang diperoleh sangat minim. Bahkan memungkinkan bisa mengalami kerugian, namun berkat perhatian dan bantuan pemerintah kondisi gagal panen dapat tertanggulangi. Informasi yang diperoleh, bantuan pemerintah yang diberikan kepada petani sejauh ini berupa alat pertanian, pupuk gratis, obat hama dan serangga. Di samping itu, masyarakat perlu memperhatikan pengelolaan pendapatan dan pengeluaran masing-masing apabila kondisi panen berhasil dan hasilnya sangat memuaskan, sebagai pertimbangan dalam menghadapi kondisi yang kurang menguntungkan.

Hasil panen pada umumnya disalurkan melalui pengepul, namun ada juga masyarakat yang menjual 
hasil panennya sampai ke pasar Marisa. Pendapatan masyarakat dari hasil panen menurut responden yang bekerja sebagai petani sudah dapat memenuhi kebutuhan sehari-hari. Selain bekerja sebagai petani, terdapat warga masyarakat yang bekerja sebagai wiraswasta dan PNS masing-masing sebesar $4 \%$. Dari sisi pendapatan, dua jenis pekerjaan ini cenderung lebih stabil dan dapat memenuhi kebutuhan sehari-hari. Di samping itu juga, masih terdapat $9 \%$ masyarakat yang tidak mempunyai pekerjaan tetap dan $25 \%$ sementara menempuh pendidikan sebagai pelajar/mahasiswa. Angka ini tergolong cukup tinggi sehingga perlu didukung oleh pihak pemerintah dalam mempertahankan bahkan meningkatkan program wirausaha dan ekonomi kreatif hingga menyentuh masyarakat Banuroja.

\section{Keterbatasan Penelitian}

Penelitian ini tentu memiliki keterbatasan dan kelemahan. Adapun beberapa hal yang berkenaan dan perlu mendapat perhatian dalam pembahasan ini, yaitu:

Pertama, dalam penelitian ini dilakukan observasi sekaligus mewawancarai sampel sebanyak 45 orang warga masyarakat. Secara ideal sampel tergolong kecil, sehingga dapat mempengaruhi pertimbangan pengambilan keputusan yang diperoleh dalam merumuskan kesimpulan.

Kedua, subjek penelitian ini hanya difokuskan pada masyarakat Banuroja. Dari sisi pembagian tiga kelompok masyarakat yang dijadikan subjek penelitian, masih memiliki ruang lingkup yang terbatas untuk digeneralisasikan dalam kondisi sosial ekonomi masyarakat daerah transmigran.

Ketiga, dalam penelitian ini hanya menggunakan beberapa aspek indikator sosial ekonomi masyarakat. Aspek lainnya seperti kesehatan, etos kerja, kelembagaan serta penggunaan teknologi, informasi dan komunikasi yang berpotensi mempengaruhi hasil penelitian ini belum dimasukkan.

\section{Penutup \\ Simpulan}

Penelitian ini memberikan gambaran bagaimana kondisi sosial masyarakat daerah transmigran Banuroja, baik golongan masyarakat transmigran, masyarakat lokal dan masyarakat campuran. Berdasarkan hasil penelitan dan pembahasan dapat disimpulkan bahwa kondisi sosial ekonomi masyarakat Banuroja menunjukkan adanya variasi prestise atau tingkat pencapaian dalam beberapa indikator kondisi sosial ekonomi, antara lain: adanya interaksi sosial yang terjalin dalam masyarakat dalam bingkai kerukunan dan toleransi yang terus dijaga; nilai-nilai kearifan lokal terus dilestarikan seiring dengan eratnya hubungan sosial masyarakat; tingkat pendidikan masih tergolong rendah yaitu terdapat $66 \%$ masyarakat yang hanya lulusan SLTP, SD bahkan belum/tidak sekolah, namun struktur penduduk menunjukkan $73 \%$ masyarakat berada pada usia produktif; mata pencaharian masyarakat sebagian besar sebagai petani, yang mengelola lahannya sendiri dengan komoditi yang beragam diantaranya kelapa, tebu, palawija, buah-buahan, dan sayuran; pendapatan yang diperoleh masyarakat 
rata-rata cukup untuk memenuhi kebutuhan sehari-hari.

\section{Saran}

1. Masyarakat Banuroja diharapkan dapat mempertahankan bahkan menguatkan semangat kekeluargaan dalam mengawal kerukunan, melestarikan budaya daerah dalam bingkai pluralisme, lebih giat untuk ikut serta dalam menuntaskan program pendidikan sebagai bentuk investasi pembangunan di masa mendatang serta terus berjuang dalam meningkatkan taraf hidupnya.

2. Pihak pemerintah maupun lembaga lainnya diharapkan terus memberikan perhatian dan sumbangsinya dalam membangun daerah perdesaan serta mengembangkan potensi yang dimiliki masyarakat daerah transmigran. Baik dari sisi kebijakan, maupun program pembangunan terutama di sektor wirausaha dan ekonomi kreatif yang dapat membuka peluang bagi masyarakat dalam meningkatkan pendapatan selain memanfaatkan hasil pertanian.

3. Pada penjelasan sebelumnya telah diungkapkan bahwa penelitian ini tidak lepas dari keterbatasan dan kelemahan. Oleh karena itu, untuk keperluan data yang lebih mendetail dan memiliki cakupan yang lebih luas terkait kondisi sosial ekonomi masyarakat daerah transmigran, perlu dilakukan penelitian lanjutan yang lebih komprehensif baik dari sisi ruang lingkup indikator fokus penelitian, waktu penelitan maupun populasi yang lebih besar.

\section{Daftar Pustaka}

Badan Pusat Statistik. 2019. Kecamatan Randangan Dalam Angka. BPS Kabupaten Pohuwato: Gorontalo Basrowi., dan Juariyah, Siti. 2010. Analisis Kondisi Sosial Ekonomi dan Tingkat Pendidikan Masyarakat Desa Srigading, Kecamatan Labuhan Maringgai, Kabupaten Lampung Timur. Jurnal Ekonomi dan Pendidikan, UNY. Vol. 7 No. 1 (2010)

Hasanuddin. 2018. Kerukunan Masyarakat Multikultur di Desa Banuroja, Gorontalo. Al-Qalam Jurnal Penelitian Agama dan Sosial Budaya, Balai Penelitian dan Pengembangan Agama Makassar. Vol. 24 No. 1 (2018)

Kohar, Wakidul, 2010. Mediating Cross Culture Theory; Teori Temuan dari Penelitian Etnografi Komunikasi Antar Budaya Era Otonomi Daerah (Studi Mikro Induktif di Nagari Lunang Sumater Barat). Innovatio. Vol. 9 No. 1 (2010)

Langumadi, Wiwin A.P., dan Harudu, La. 2017. Kondisi Sosial Ekonomi Masyarakat Transmigran di UPT Arongo Desa Persiapan Bosenga Indah Kecamatan Landono Kabupaten Konawe Selatan. Jurnal Penelitan Pendidikan Geografi, Universitas Halu Oleo. Vol. 1 No. 2 (2017)

Miles dan Huberman. 1984 (Dalam Sugiyono: 2017). Analisis Data Model Miles dan Huberman. Alfabeta : Bandung.

Monografi Desa Banuroja Tahun 2019

Nova, Yosi. 2016. Dampak Transmigrasi Terhadap Kehidupan Sosial Masyarakat: Studi Sejarah Masyarakat Timpeh Dharmasraya. 
Jurnal Ilmu Sosial Mamangan,

STKIP PGRI Sumater Barat. Vol. 5

No. 1 (2016:23-36)

Riady, M. Gunthar. 2004. Adaptasi

Masyarakat Transmigran dan

Beberapa Faktor yang

Mempengaruhinya (Studi Kasus di

Daerah Pemukiman Transmigrasi

Kota Bangun Propinsi Kalimantan

Timur). Etnovisi, Jurnal

Antropologi Sosial Budaya. (2004)

Peraturan Pemerintah Nomor 2 Tahun

1999 tentang Penyelenggaraan

Transmigrasi

Sugiyono. 2017. Metode Penelitian Kualitatif. Alfabeta : Bandung

Sukirno, Sadono. 2004. Pengantar Teori Makroekonomi. Alfabeta : Bandung

Undang-Undang Nomor 15 Tahun 1997 tentang Ketransmigrasian

Yuliati, Yayuk. 2003. Sosiologi Pedesaan.

Raja Grafindo Persada: Jakarta 